\title{
THE USE OF IT TECHNOLOGIES IN FARMS ON THE EXAMPLE OF ZAMBRÓW AND WYSOKIE MAZOWIECKIE COUNTY
}

\author{
Andrzej Borusiewicz ${ }^{\mathrm{a}}$, Krzysztof Kapela ${ }^{\mathrm{b}^{*}}$, Marek Gugała ${ }^{\mathrm{b}}$ \\ ${ }^{a}$ Faculty of Computer Studies, The Academy of Agrobusiness in Lomza \\ ${ }^{\mathrm{b}}$ Department of Agronomy, Siedlce University of Natural Sciences and Humanities \\ "Corresponding author: e-mail: krzysztof.kapela@uph.edu.pl
}

\begin{tabular}{ll}
\hline ARTICLE INFO & ABSTRACT \\
$\begin{array}{l}\text { Article history: } \\
\text { Received: February } 2016\end{array}$ The paper presents the analysis of use of IT technologies by farmers. \\
$\begin{array}{l}\text { Received in the revised form: } \\
\text { Accepted: April } 2016\end{array}$ & $\begin{array}{l}\text { Data from a research survey carried out in } 100 \text { randomly selected } \\
\text { farms in } 2015 \text { constituted research material. The research area covered } \\
\text { farms located in Podlaskie Voivodeship on the area of two counties }\end{array}$ \\
$\begin{array}{ll}\text { Key words: } \\
\text { agricultural farm, } \\
\text { Internet, computer, } \\
\text { computer program, } \\
\text { agriculture }\end{array}$ & $\begin{array}{l}\text { i.e. Wysokie Mazowieckie (50 questionnaires) and Zambrów County } \\
\text { research was to determine the level of use of specialist computer } \\
\text { programs by farmers and their needs concerning acquisition of infor- } \\
\text { mation on innovations in agriculture. Due to the obtained results one } \\
\text { may find out that a low number of farmers uses specialist computer } \\
\text { programs in their farms. In Wysokie Mazowieckie County it is only } \\
8 \% \text { of respondents and in Zambrów County 14\%. The main source of } \\
\text { information on innovations in agriculture is the Internet, professional } \\
\text { agricultural press and television. }\end{array}$ \\
\hline
\end{tabular}

\section{Introduction}

In the recent years merging of two various fields such as IT and communication technology (ICT) and agriculture has become a fact. A computer with an access to the Internet can be used in numerous ways in agriculture. The Internet for a farmer may be a source of cognitive (legislation, communications, data bases) as well as decisive information (procedures, rules, management, marketing and finances) (Kavka et al., 2007). It may also considerably improve conditions of business activity which for farmers means that they can apply for area subsidies online and send them for verification to the Agricultural Extension Centre without visiting a consultant (Kapela et al., 2012).

Electronics which operates on-board computers of agricultural machines and devices is compatible with software of home computers. Internet services are cheaper and more available. A computer with the Internet is nothing extraordinary in a household. IT technologies which aim at farms management in the countries with a high level of agricultural production has been widely implemented (Coolman, 2002). In the 90's of the previous century, computer advisory systems of farm management have developed. At the same time, their uneven use in farms with a similar size and agricultural production profile is reported (Verstegen et al., 2001). The reason for reluctance and lack of trust of farmers concerning im- 
plementation of the management support systems in Polish farms is a fear that the costs of purchase of the computer equipment and software may not be compensated with savings made thanks to their use (Grudziński, 2006). The research carried out by Lorencowicz and Figurski (2008) show that only $10 \%$ of farmers used specialistic and advisory programs in the analysed farms.

Farmers not always are aware that the use of IT technologies in a farm facilitates its development and forces farmers to acquire new skills. Each farmer who wants to keep the pace with changes of the modern market must have ability for constant development, inter alia, through extending their knowledge (Roszkowski, 2004; Zaliwski et al., 2007).

\section{Objective, scope and methodology of research}

The research aimed at determination of the level of use of computer programs which support management and production in a farm by farmers from two counties: Zambrów and Wysokie Mazowieckie. Moreover, sources of information on modern agriculture by farmers were identified. The source of primary information consisted of a questionnaire research carried out in 2015 with the use of a direct survey method. After completeness and reliability of data for analysis were verified, 50 questionnaires were selected. They were completed by owners of farms located in Zambrów County and the same number of questionnaires completed by farmers from Wysokie Mazowieckie County. Farms specializing in cattle breeding were selected and owned more than 10 ha of AL. The questionnaire was divided into two parts. The first concerned information on a farm owner and his farm and the second consisted of questionnaires concerning specialist computer programs designed for agriculture and sources of information on agriculture.

The questionnaire contains, inter alia, questions concerning the education level of a farm owner, the scope of use of information (sources of information, necessary information) and computer programs which farmers use or would like to use.

\section{Research results}

The most numerous age group among the questioned farmers from Wysokie Mazowieckie County consisted of farmers in the age group 46-55-28\%. Zambrów County was the most represented by farmers between 36 and 45 years of age $-44 \%$. Almost $46 \%$ of farmers from Wysokie Mazowieckie County and 30\% from Zambrów County had secondary school education. Respectively $32 \%$ and $40 \%$ of the investigated farmers had higher education and $22 \%$ and $30 \%$ a vocational one. Any of the questioned farmers did not have education level lower than vocational.

The obtained answers concerning the area of the farm prove that $34 \%$ of farmers from Wysokie Mazowieckie County and 22\% from Zambrów county had farms in the area range of 11-20 ha and only respectively $4 \%$ and $12 \%$ within $51-100$ ha. In the investigated group of farms $6 \%$ had area above 100 ha. They were located in Zambrów County. Corn - 57\% designated for silage for dairy cattle $-80 \%$ participation in the structure of animal production prevailed in the sowing structure of the investigated group of farms.

The research carried out in farms from Wysokie Mazowieckie and Zambrów County prove that specialist computer programs are used by farmers to a small extent (Fig. 1). Also 
The use of it technologies...

Kocira and Lorencowicz $(2008,2011)$ who carried out research among farmers on the area of Lubelskie Voivodeship point at low - only $20 \%$ use of management and production supporting programs in a farm and no interest in this type of programs on farmers' part.

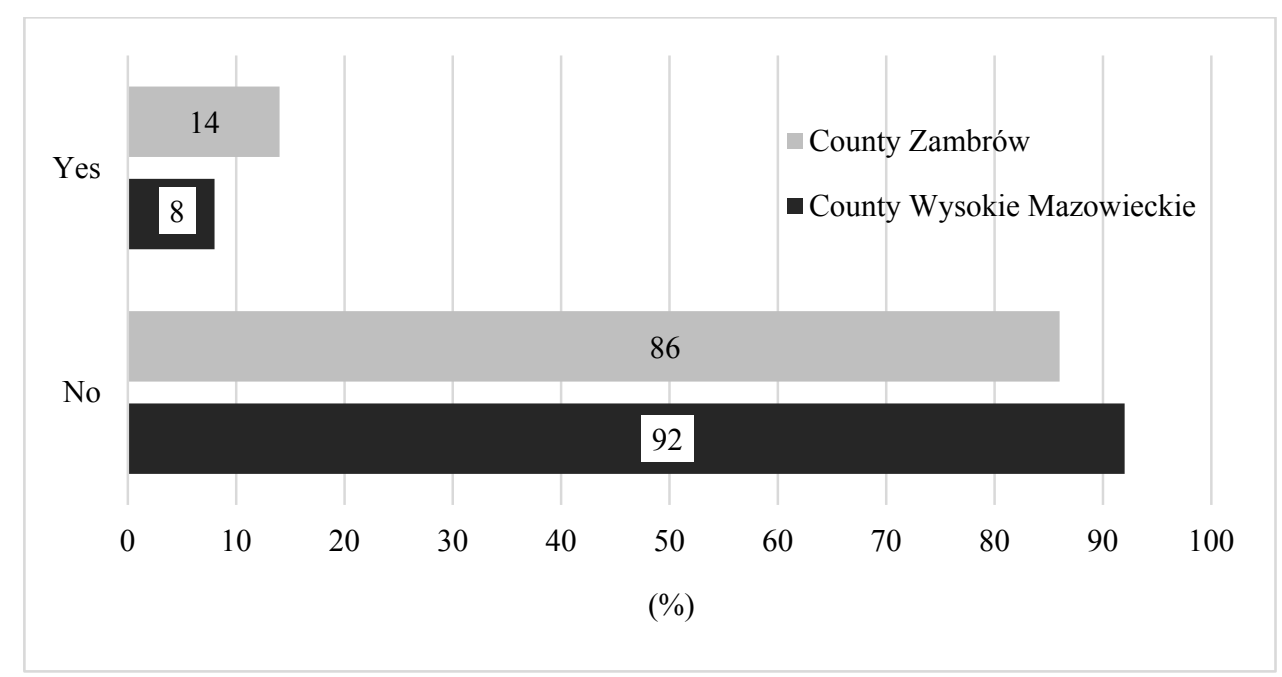

Figure 1. Use of specialist computer programs in the investigated farms of Wysokie Mazowieckie and Zambrów County

As much as $86 \%$ of questioned farmers from Zambrów County and $92 \%$ of all investigated farmers in Wysokie Mazowieckie County does not use computer programs which support agricultural production. The research carried out by Kapela and Borusiewicz (2012) shows that on the territory of Podlaskie Voivodeship in the investigated group of farmers, majority because as much as $65 \%$ of all owned such programs. "Obora" and "WinPasze" programs prevailed among programs used by respondents. When Borusiewicz (2009) analysed the use of computer programs by farmers from Łomża County he stated that the most often used programs are those which support plant production $(55 \%)$, animal production $(16 \%)$, accounting programs $(27 \%)$ and catalogues and data bases $(2 \%)$.

The research which was carried out proves that despite low use of specialist computer programs, the questioned farmers are aware that such type of programs are helpful in carrying out a farm. This is the opinion of $78 \%$ of the surveyed farmers from Wysokie Mazowieckie County and 70\% from Zambrów County (Fig. 2). Research carried out by Borusiewicz and Kapela (2012) prove that owners of farms which specialize in milk production from the territory of Kolno County see the need to have a specialist computer program. As much as $43 \%$ of respondents said that such programs are indispensable. Also Szewczyk (2010) in his survey among farmers from Jędrzejów County in Świętokrzyskie Voivodeship proved that they $(46 \%)$ are very positive about the usefulness of computer programs in running and management of farms. 
Andrzej Borusiewicz, Krzysztof Kapela, Marek Gugała

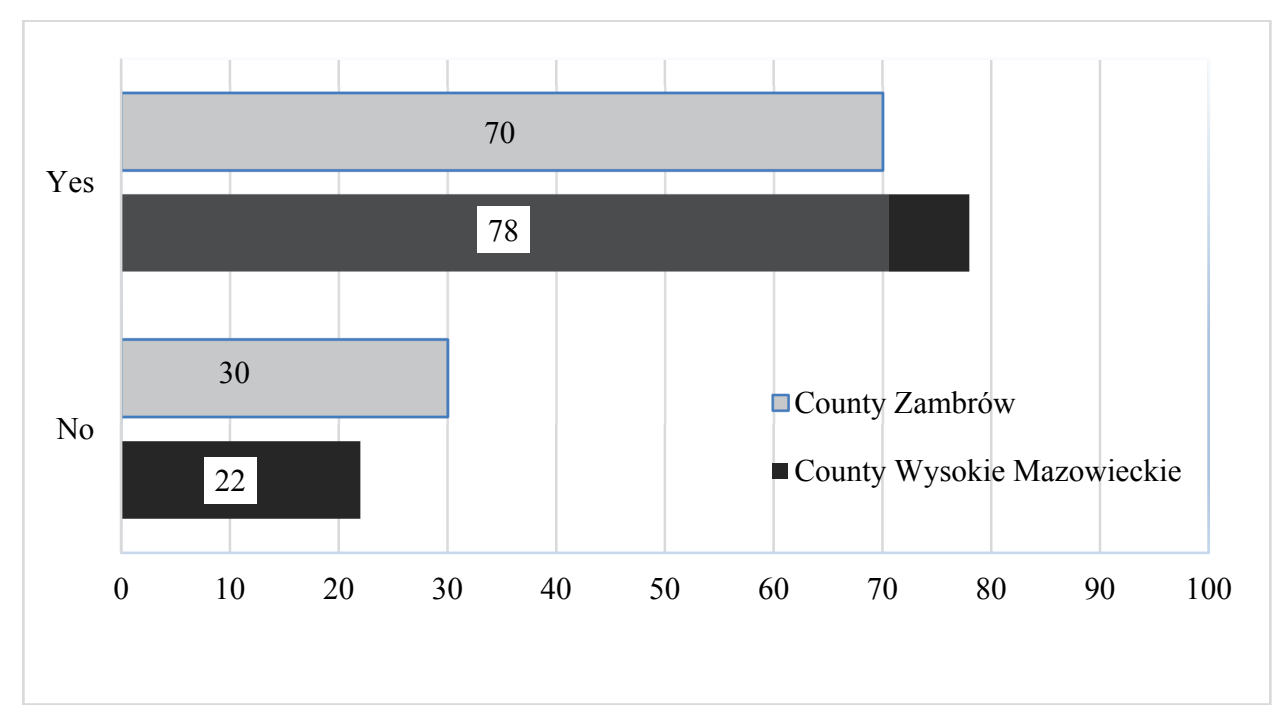

Figure 2. Farmers' opinion on the need of having specialist computer programs in their farms

One of the questions posed to respondents, concerned indication of expectations from the use of computer programs concerning help and facilitation of the operation of production processes in farms and taking up proper decisions. The highest number of farmers from Wysokie Mazowieckie County concerned support of work organization in a farm - 13\%, support of animal feeding and correct fertilization - each 12\% (Fig. 3). Respondents from Zambrów County were the most interested in programs which support fertilization $-21 \%$ of indications, plant protection $-20 \%$ and planning feed doses for animals (20\%) (Fig. 4). Also Francik (2010) showed in his research that farmers would like to use mainly computer programs which support fertilization and plant protection and which help in filling applications. They are also interested in applications which serve for making record of fields, determination of feed doses and organization of field works.

The last question in the questionnaire aimed at obtaining from respondents information on the knowledge on innovations in agriculture. The answers were varied. Farmers from Wysokie Mazowieckie County indicated the Internet $-31 \%$ and professional agricultural press $-29 \%$ as basic sources of information. TV programs $(15 \%)$ and information obtained from other farmers (13\%) were on a further position (Fig. 5).

Farmers from Zambrów County indicated agricultural press $-28 \%$ as a basic source of information on innovations in agriculture and websites and TV $-22 \%$ on the second position. They use information obtained from agricultural consultants more often than farmers from Wysokie Mazowieckie County - 8\% (Fig. 6). The research carried out by Francik (2010) proves that television is a basic source of specialist information. Also Cupiał (2006) proved in his research that television is a form of obtaining information preferred by farmers $(61 \%)$. As the results of research carried out by other authors show, the basic source of market information for farmers consists in television and agricultural press (ŚmiglakKrajewska and Zielińska, 2009). 
The use of it technologies...

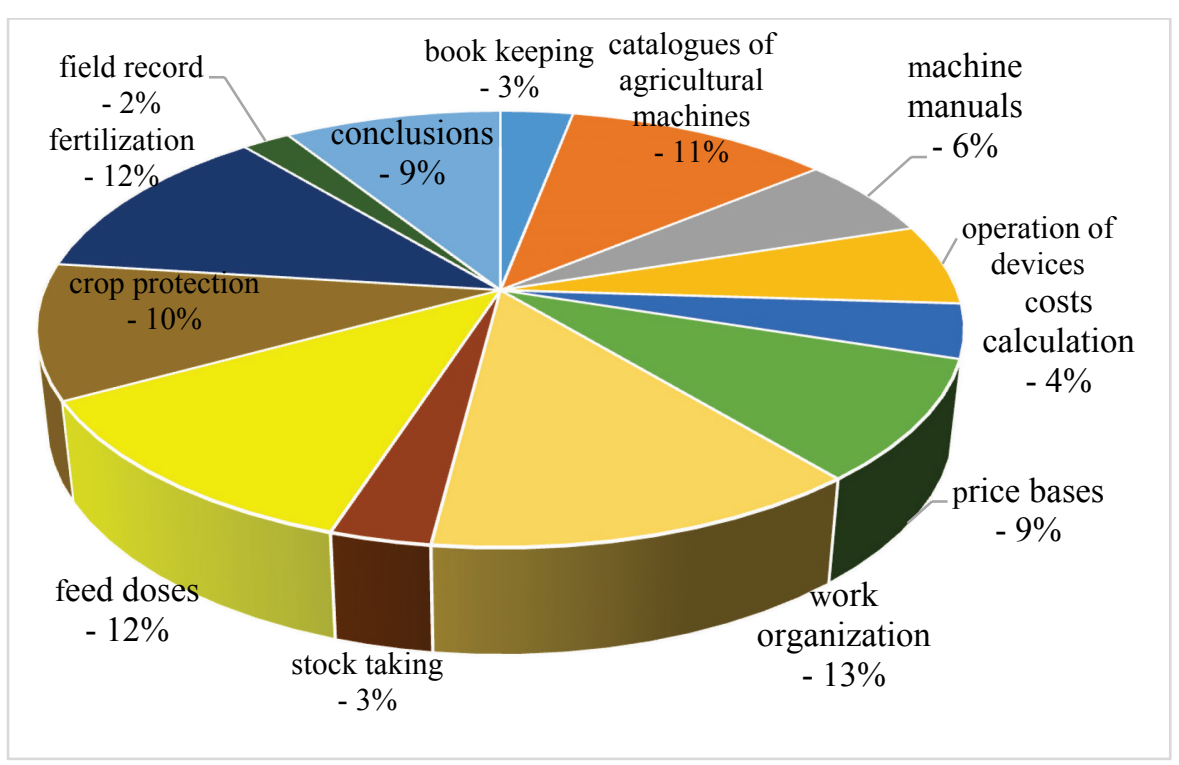

Figure 3. Indications of farmers from Wysokie Mazowieckie County concerning type of actions which could be supported by specialist computer programs

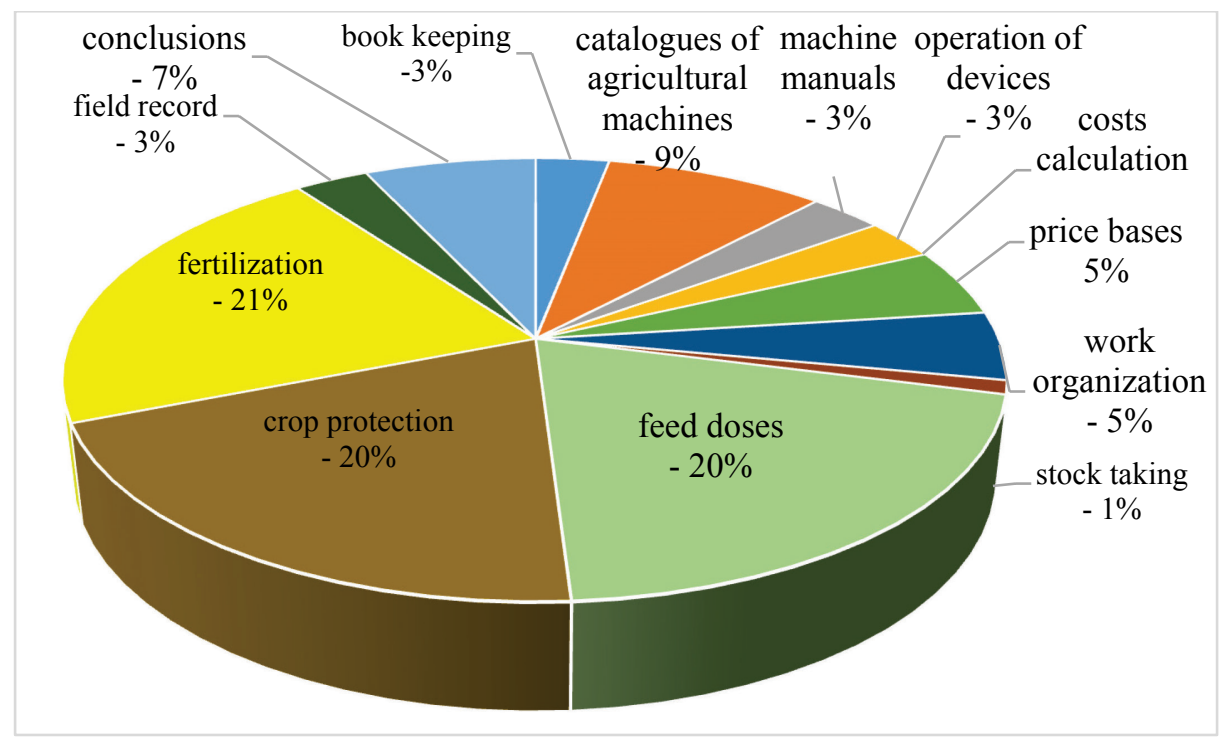

Figure 4. Indications of farmers from Zambrów County concerning type of actions which could be supported by specialist computer programs 
Andrzej Borusiewicz, Krzysztof Kapela, Marek Gugała

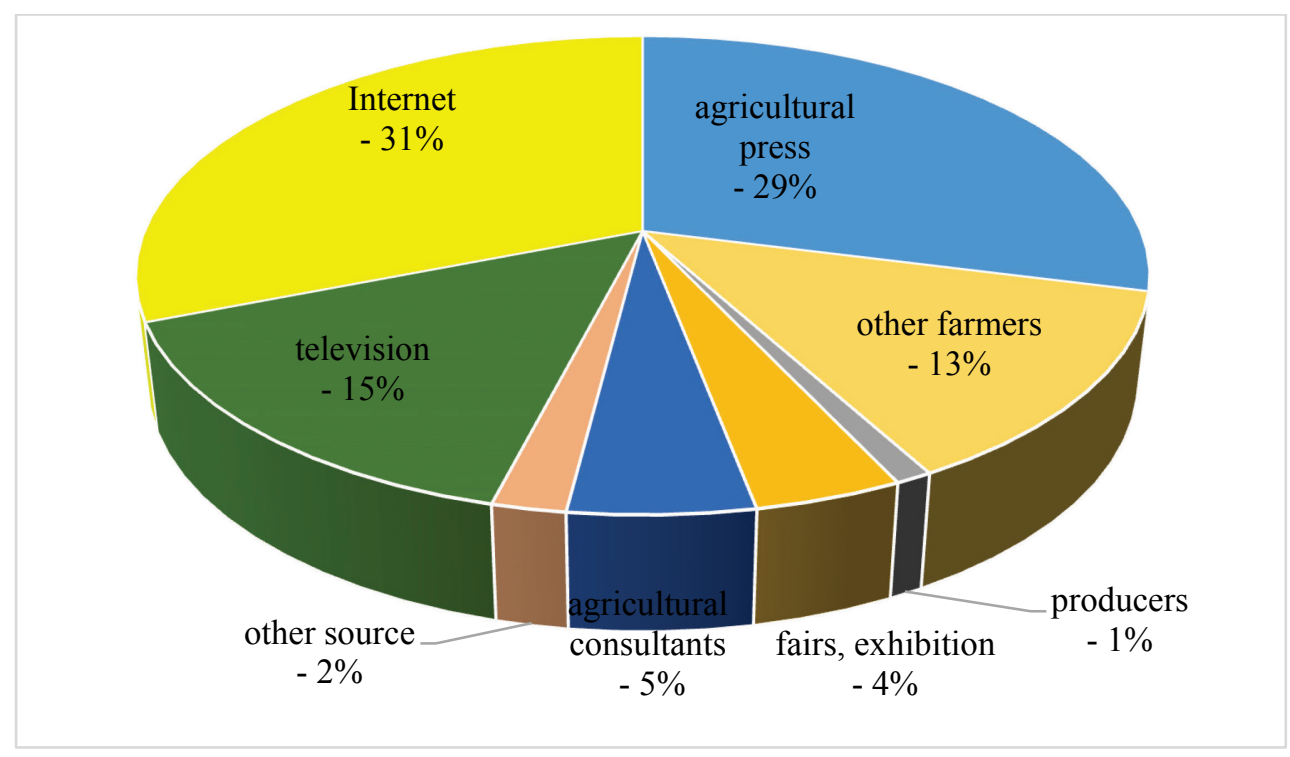

Figure 5. The sources of information on agriculture according to indications of respondents from Wysokie Mazowieckie County

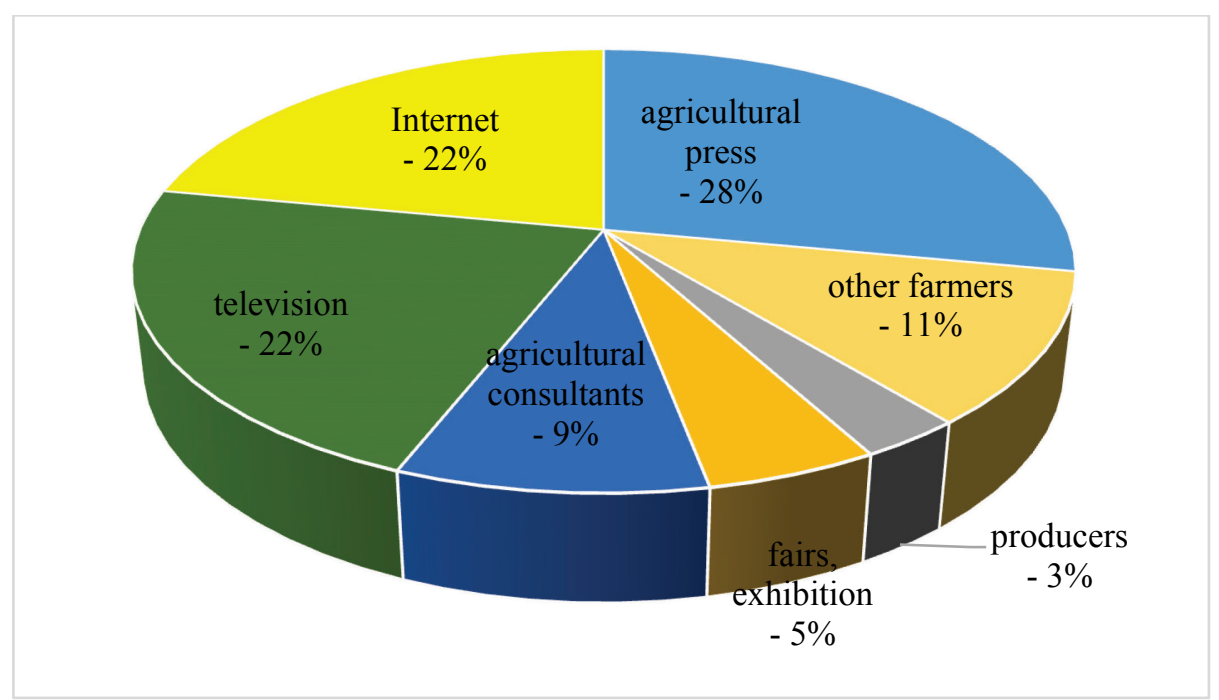

Figure 6. The sources of obtaining information on agriculture according to indications of respondents from Zambrów County 
The use of it technologies...

\section{Conclusion}

The research which was carried out proved that farmers, despite high awareness of advantages $(78 \%$ of respondents in Wysokie Mazowieckie County and $70 \%$ in Zambrów County) resulting from having specialist computer programs in a farm, use them rarely $8 \%$ of respondents from Wysokie Mazowieckie County and 14\% from Zambrów County. It may result from the fact that there are no trainings or any other forms of teaching on the possibilities of using programs, their operation and correct interpretation of the analyses results. Agricultural extension centres and agricultural universities should aid farmers within this scope through organization of trainings concerning the use and operation of specialist computer programs.

Respondents from Wysokie Mazowieckie County would most eagerly use computer programs which support work organization in a farm $-13 \%$, animal feeding and correct fertilization $-12 \%$ each. Respondents from Zambrów County would be the most interested in programs which support fertilization $-21 \%$ of indications, plant protection $-20 \%$ and planning feed doses for animals (20\%). Over 30\% of farmers from Wysokie Mazowieckie County declare that their main source of information on agriculture is the Internet. $28 \%$ of respondents from Zambrów County when asked where they obtain information on innovations, agricultural news, despite the fact that they declared the Internet as a very significant source of information $-22 \%$, they reach for professional agricultural press.

\section{References}

Muzalewski, A. (2009). Wykorzystanie specjalistycznych programów komputerowych i Internetu w gospodarstwach rolnych. Acta Scientiarum Polonorum, Technica Agraria, 8(3-4), 3-8.

Borusiewicz, A., Kapela, K. (2012). Ocena wykorzystania technologii IT w gospodarstwach specjalizujących się w produkcji mleka na terenie powiatu kolneńskiego w woj. podlaskim. Agricultural Engineering, 2(137), 7-16.

Coolman, F. (2002). Developments in Dutch farm mechanization: past and future. Agricultural Engineering International, Vol. IV, 1-10.

Cupiał, M. (2006). System wspomagania decyzji dla gospodarstw rolniczych. Inżynieria Rolnicza, 9(84). Monografia. ISSN 1429-7264.

Francik, S. (2010). Analiza wykorzystania przez rolników programów komputerowych do wspomagania decyzji. Agricultural Engineering, 7(125), 47-54.

Grudziński, J. (2006): Technologie informacyjne w systemach doradczych zarządzania gospodarstwem rolnym. Agricultural Engineering, 5(80), 207-213.

Kapela, K., Borusiewicz, A. (2012). Wykorzystanie technologii informacyjno-telekomunikacyjnych (ICT) w wybranych gospodarstwach rolnych województwa podlaskiego. Agricultural Engineering, 2(136), 121-128

Kavka, M., Trávníček, Z., Kavka, P., Kavka, P., Dobek, T. (2007). System informacyjny wykorzystywany w doradztwie rolniczym na terenach wiejskich. Agricultural Engineering, 2(90), 85-91.

Kocira, S., Lorencowicz, E. (2008). Wykorzystanie komputerów w wybranych gospodarstwach rodzinnych Lubelszczyzny. Agricultural Engineering, 7(105), 109-115.

Kocira, S., Lorencowicz, E. (2011). Wykorzystanie technik komputerowych w gospodarstwach rodzinnych. Agricultural Engineering, 6(131), 77-83.

Lorencowicz, E., Figurski, J. (2008). Ocena wykorzystania komputerów i Internetu w indywidualnych gospodarstwach rolnych. Acta Scientiarum Polonorum, Technica Agraria, 7(3-4), 29-34. 
Roszkowski, A. (2004). Informatyka w rolnictwie - najważniejsze aspekty zastosowania. Materiały konferencyjne Krajowe Centrum Doradztwa Rozwoju Rolnictwa i Obszarów Wiejskich (on-line), ISBN 83-88082-31-0. Obtained from: www.cbr.edu.pl/konferencja_pliki/program_tezy_14_09 doc

Szewczyk, J. (2010). Badania poziomu komputeryzacji gospodarstw rolnych w województwie świętokrzyskim. Stowarzyszenie Ekonomistów Rolnictwa i Agrobiznesu, Roczniki Naukowe, Tom XII, Zeszyt 3, 400-404.

Śmiglak-Krajewska, M., Zielińska, A. J. (2009). Informacja rynkowa jako czynnik wspomagający zarządzanie ryzykiem w agrobiznesie. Journal of Agribusiness and Rural Development, 1(11), 189-197.

Verstegen, J.A.A.M., Huirne, R.B.M. (2001). The impact of farm management on value of management information systems. Computers and Electronics in Agriculture, 30, 51-69.

Zaliwski, A. S., Pietruch, C. (2007). Narzędzia informatyczne w produkcji roślinnej. Agricultural Engineering, 2(90), 333-339.

\section{WYKORZYSTANIE TECHNOLOGII INFORMATYCZNYCH W GOSPODARSTWACH ROLNYCH NA PRZYKLADZIE POWIATU ZAMBROWSKIEGO I WYSOKOMAZOWIECKIEGO}

Streszczenie. W pracy przedstawiono analizę użytkowania przez rolników technologii informatycznych. Materiał badawczy stanowiły dane pochodzące $\mathrm{z}$ badań ankietowych przeprowadzonych $\mathrm{w} 100$ losowo wybranych gospodarstwach rolnych w 2015 roku. Obszarem badań objęto gospodarstwa położone w województwie podlaskim na terenie dwóch powiatów tj. wysokomazowieckiego (50 ankiet) oraz zambrowskiego (50 ankiet). Instrumentem badawczym był kwestionariusz wywiadu. Badania miały na celu określenie poziomu wykorzystania przez rolników specjalistycznych programów komputerowych, a także jakie są ich potrzeby w zakresie pozyskiwania informacji o nowościach w rolnictwie. Uzyskane wyniki badań pozwalają stwierdzić, iż niewielka liczba rolników wykorzystuje specjalistyczne programy komputerowe w swoim gospodarstwie. W powiecie wysokomazowieckim tylko $8 \%$ respondentów a w powiecie zambrowskim 14\%. Głównym źródłem pozyskiwania informacji o nowościach $\mathrm{w}$ rolnictwie jest Internet, fachowa prasa rolnicza oraz telewizja.

Słowa kluczowe: gospodarstwo rolne, Internet, komputer, program komputerowy, rolnictwo 